\title{
Currency Policies and the Nature of Litigation in Colonial New England
}

Judicial enforcement of debt agreements was one of the central and most important aspects of government promotion of the nascent colonial economy. ${ }^{1,2}$ Nevertheless, legal historians have characterized the colonial court system in contrasting terms as a bulwark of pre-industrial cultural norms impeding development, or as a crucial catalyst of commercial transformation. In either case, legal historians' focus on law developed in the courts, as opposed to the policies of the legislative or executive branchs of government, has led to an assumption that the law adjusts in some natural way to changing economic and cultural climates. According to this view, lawsuits are an indirect reflection of prevailing cultural norms and market conditions. Judges adapt the law as those norms and conditions change. The court system therefore fulfills an institutional role of ensuring that the law keeps pace with economic and societal transformation, and comes close to optimally satisfying the legal needs of local communities.

The most prominent description of the insular and community-oriented base of colonial law is Morton Horwitz's The Transformation of American Law, 1780-1860. Horwitz emphasizes the centrality to eighteenth-century law of limitations on market activity such as the just price and usury doctrines, contracts involving transfers of property rather than monetary payments, and damages based on equity and fairness rather than on satisfying expectations ${ }^{3}$ Emphasizing the prevalence of litigation based on direct property exchanges, Horwitz concludes that the law reflected undeveloped markets and a community-oriented society in which goods "were usually not thought of as being fungible. . . . [and] [e]xchange was not conceived of in terms of future monetary return." ${ }^{\prime 4}$ To Horwitz, colonial law reflected a pre-industrial communitarian mindset, "essentially antagonistic to the interests of commercial classes," in which justification for contractual obligation was "the inherent justice or fairness of an exchange." Colonial law applied by judges, therefore, reflected the values associated with pre-industrial, agrarian societies. In this respect, Horwitz contrasts the judicial doctrine of the eighteenth century with that of the nineteenth century, when judges began using common law instrumentally to promote capitalist values and a market economy. With regard to both the colonial period and the nineteenth century, however, Horwitz portrays the law as harmoniously synchronized to advance prevailing cultural norms and preferences regarding economic activity.

More recently, Bruce Mann's Neighbors and Strangers: Law and Community in Early Connecticut presents a contrasting interpretation of colonial law and its relation to market development. Mann examined changes observable in litigation data, rather than changes in legal doctrine. He found that litigation related to book accounts domi-

${ }^{1}$ This dissertation was completed under the direction of Robert W. Gordon at Yale Law School.

${ }^{2}$ Debt litigation dominated the caseload of the colonial courts. Debt cases, for example, constituted 74 percent of all cases heard during the period 1725 to 1774 in the Plymouth, Massachusetts County Court of Common Pleas, the court of original jurisdiction for civil (noncriminal) lawsuits. See Nelson, Dispute, pp. 23-24.

${ }^{3}$ See Horwitz, Transformation, pp. 160-73.

${ }^{4}$ Ibid., pp. 162-63.

${ }^{5}$ Ibid., p. 167.

${ }^{6}$ Ibid., p. 160. 
nated the court dockets in the seventeenth century. ${ }^{7}$ Book account disputes were frequently contested in court, and judges in these cases tailored their decisions to the individual litigants and their unique circumstances. By the 1720s and 1730s, however, Mann found that litigation had changed in two ways. First, the debt cases that were litigated increasingly involved formal credit instruments, the terms of which left little to dispute in court. Greater use of formal credit instruments therefore corresponded closely with an increasing percentage of debt cases ending in a default judgment (where the debtor did not appear to contest the dispute) or confession of judgment (where the debtor conceded responsibility for the debt). Second, the volume of litigation increased exponentially-beyond population growth-over the first half of the eighteenth century.

Mann interprets the default judgments as creditors and debtors using the court system to record debts in the courts' registers. Default judgments allowed creditors to establish their "place in line" to debtors' assets. Default judgments also secured creditors' interests in debtors' property by allowing quick execution (seizure and possibly sale of the debtors' property by sheriffs) at their discretion. Debtors acquiesced to the entry of judgments against them by default because they too benefited from the bureaucratization of credit, possibly from lower interest rates. According to Mann, "credit had become something extended in single transactions in return for formal admissions of liability." 8 Thus, to Mann, the high percentage of cases ending in default indicates the creation of a modernized mechanism for debt recording, similar in kind to today's perfection of security interests through Article 9 of the Uniform Commercial Code.

In Mann's account, the bureaucratization of the courts' role reflected an institutional transformation resulting from economic advance and the commercialization of the society. In sum, economic advance led to more transactions that crossed community lines. Formal credit instruments, which were difficult to contest in court, were better suited for impersonal contractual relations. Presumably to lower interest rates, creditors and debtors recorded default judgments at the time debt agreements were entered into. In the process, the courts' primary function changed from dispute-resolution to debt recordation. An institutional base of the colonial economy transformed to accommodate economic growth and commercialization. ${ }^{9}$

My Dissertation presents a starkly different view of the colonial court system's role in the economy. The Dissertation presents the results of an empirical study (described below) demonstrating that default judgments were not a rationalized means of security recordation, but represented real defaults, that is, creditors using litigation to collect debts when debtors failed to pay after the terms of their loans had passed. Moreover, I

\footnotetext{
${ }^{7}$ Book accounts were records (like a tab) of goods or services others took on credit. In the colonial period, in addition to being used in more formal creditor-debtor relations, people in a community established accounts with each other, taking goods and services on credit, and gradually reciprocating by exchanging different goods and services over time.

${ }^{8}$ Mann, Neighbors, p. 40.

${ }^{9}$ In one passage, for example, Mann states that: "An expanding economy requires that individual transactions be governed by generally applicable rules. Because of the sheer number of such transactions and the distances they may involve, they have to be conducted in a routine fashion. Their form and the legal rules that direct them must be uniform and calculable. Rational economic exchange requires the assurance that like cases will be treated alike. To provide that assurance, general rules override the individuality of particular cases and force them into a common mold. Formal requirements that limit litigation to the instruments themselves and restrict appeals homogenize the underlying transactions and give them a uniform, predictable legal character." Neighbors, p. 36.
} 
empirically examined the level of court fees imposed on the litigants in relation to the debts that ended in default judgment and found them to be so high as to create a disincentive to record debts during stable economic conditions. ${ }^{10}$ How, then, should we characterize the nature of debt litigation, and how should we explain the exponentially increasing volume of litigation in the first half of the eighteenth century and, more generally, the colonial court system's role in the economy?

Relying on extensive research of primary materials, my Dissertation emphasizes the ways in which currency policies enacted by colonial assemblies, mercantilist policies adopted by Parliament and the Board of Trade in England, as well as domestic and international economic conditions, influenced the forms in which people transacted and the volume of litigation. Colonial governments began issuing paper fiat currencies in the late seventeenth and early eighteenth centuries as a method of financing increasing military expenditures. Each colony's annual determination of the paper currency in circulation reflected a struggle within colonial assemblies, which faced pressure from part of the public - often debtors - to issue paper money in greater volume, and conflicting pressure from English and New England merchants who desired a stable currency of high value to satisfy English import debts. In New England, the tensions between the elected, representative assemblies and the English-representatives of a foreign sovereign promoting a mercantilist agenda - led to policies that created disastrous uncertainty. New England experienced periods of steady inflation as well as of currency scarcity, when colonial citizens were forced to use promissory notes as a substitute for cash, and to revert to commodity money exchange and barter-like transactions, such as paying laborers in shop notes.

I present data revealing that periods of exponentially increasing litigation coincide with economic conditions and the periods of greatest uncertainty relating to government currency policies. In a context of high court fees that would ordinarily deter litigation, exponentially increasing litigation can be attributed to two economic conditions. First, litigation increased during times of economic recession and monetary scarcity, often driven by depressed credit conditions in Britain, when debtors on a widespread basis were simply unable to pay their debts. Second, litigation increased in response to inflation and uncertainty about colonial governments' currency policies. During periods of inflation, or when the public predicted inflation based on the governments' inability to commit to its currency policies, debtors failed to repay their debts as a delaying tactic to benefit from declining currency values, forcing their creditors to sue. Inflation lowered the real value of court fees as well as the underlying debts. I trace the effects on litigation of British mercantilist and domestic currency policies in a detailed account of the first half of the eighteenth century in Massachusetts.

In contrast to the optimistic rendering of the courts in the standard account, contemporary pamphlets concerning Massachusetts's currency policies show that colonial citizens were frustrated by the swamping of the courts with debt-related litigation during periods of currency instability, that some complained bitterly about excessive court fees, and that serious questions were raised about judges' dogged enforcement of the common law principle of nominalism - allowing debtors to satisfy their debts with payment in nominal, not real, values of the debts. In a 1743 pamphlet, one writer claimed about nominalism that:

${ }^{10}$ In the Plymouth County Court of Common Pleas in 1740, for example, fees comprised an astounding 79 percent of the underlying debt for the quartile of cases reflecting the smallest debts. The average and median court fee / debt ratios for all cases were a substantial 32.6 percent and 21.7 percent, respectively. 
This [legal tender] Law . . . habituat[ed] Debtors to suffer themselves to be sued for indisputable Debts, and to appeal from Judgments obtain'd against 'em upon their own Defaults to the Superior Court merely for Delay ... [T]his Sort of Actions multiply'd in Proportion, to the great Hurt and Scandal of the Country; insomuch that the Number of such Suits within the Province was increas'd . . Between the Years 1730 and 1742, to near double what it was before. ${ }^{11}$

Thomas Hutchinson (the future Governor) wrote in 1736 that: "[T]he Government is the Guarantee that all just \& legal Contracts shall be perform'd; but with us they are daily broken, \& necessarily will be so, whilst our Money continues in its present fluctuating Circumstances."12

Mann's interpretation of litigation, that "debtors conceded liability before payment for their creditors' convenience," 13 assumes a key empirical fact: that litigation will occur close in time to the execution of the debt agreement. The ambition of debt recordation is to establish a legal priority to a debtor's assets. Delay of any period reduces the value of the debt by affording an opportunity for other creditors to establish claims prior or equivalent to the previously extended debt. Using the records of the Plymouth County courts, I examined over 3500 cases ending in a default judgment in the period 1724 to 1750 to determine the length of time between the date the parties entered debt agreements and the date creditors filed suit to collect. ${ }^{14}$ My interpretation - that confessed judgments and defaults in the first half of the eighteenth century primarily represented real defaults-implies an interval between debt execution and litigation beyond the term of the debt.

The customary terms of credit extended to local retailers in the period ranged from six to twelve months, though sometimes less. ${ }^{15}$ I found that the median interval between debt agreement and litigation for all debt litigation ending in default between 1724 and 1750 was 531.5 days (17.5 months). Only $14.5 \%$ of all debt cases resulting in default were litigated within six months of the execution of the debt agreement. I therefore concluded that the vast majority of default judgments - that is, at least $85.5 \%$-represented litigation after real defaults. Periods of a high litigation volume would therefore reflect widespread economic distress or a delaying tactic in anticipation of inflation, rather than, as Mann suggested, the extension of credit and an agreement between debtors and creditors to secure debts with default judgments.

Anecdotal evidence in historians' accounts confirms that litigation was "a last resort" for creditors and, indeed, that colonial creditors incurred great costs to obtain information about debtors' financial status and to keep any negative information secret

${ }^{11}$ An Enquiry into the State of the Bills of Credit of the Province of Massachusetts-Bay in New-England in a Letter From a Gentleman in Boston to a Merchant in London (n.p. 1743), reprinted in Davis, Colonial Currency Reprints, vol. 4, pp. 162-63.

${ }^{12}$ A Letter to a Member of the Honourable House of Representatives, on the Present State of the Bills of Credit (Boston, n.p. 1736), reprinted in Davis, Colonial Currency Reprints, vol. 3, pp. 160-61. I found strong ties between currency policies, debt litigation, and the seeds of Revolution in Massachusetts. During a period of severe currency scarcity (and high levels of debt litigation), there emerged a widespread popular movement to establish a private bank, backed by land. Parliament suppressed the Land Bank by applying the Bubble Act to the colonies in 1740. John Adams later claimed that the "act to destroy the Land Bank scheme raised a greater ferment in this province than the Stamp Act did." Adams, Works, vol. 4, "Novanglus," p. 49 (emphasis added).

${ }^{13}$ Mann, Neighbors, p. 45.

${ }^{14}$ Konig, Plymouth Court Records.

${ }^{15}$ See Harrington, New York Merchant, p. 101, suggesting between 3 and 12 months as the customary terms for domestic credit; and Soltow, Economic Role, p. 133, describing customary domestic credit terms as between 6 and 12 months. 
from other creditors in order to avoid having to sue. ${ }^{16}$ As described by A.G. Roeber, court sessions were widely attended and, indeed, "Court days" were regional, popular events, in part, because they were the best time for creditors to see "who was recovering against whom and what their own roles might be at any given moment." of court days, creditors worked to keep negative information about debtors' financial status secret, according to Virginia Harrington, because "every creditor hoped to be able to collect his debts before the insolvency of the debtor became generally known."18

My account of the nature of colonial debt litigation is further confirmed by the events of Shays' Rebellion, which in 1786 and 1787 constituted a widespread attack on the structure of the colonial court system, culminating in the violent takeover and closing of many county courts in western Massachusetts and throughout New England. The Shaysites (who referred to themselves as Regulators) condemned its injurious costliness, its fee structure which, they claimed, enabled judges, witnesses, and sheriffs to profit at the expense of litigants, and its cooptation by lawyers. Defenders of the regime dismissed the Regulators as "men in distress involved in debt and discontented"19 and desiring "equal distribution of property," and "the annihilation of debts." ${ }^{20}$ Several of the Regulators' principal court reform proposals, however, were designed chiefly to reduce costs and administer justice more effectively. One Regulator proposed adopting a system according to which creditors and debtors could inexpensively record and secure debts, for example, by substituting the common pleas courts with "courts of record" that would specifically provide a debt-securing and recording service. ${ }^{21}$ The General Court responded by enacting the Confession Act of $1786,{ }^{22}$ which allowed debtors to avoid costly litigation in any debt case by "confessing" judgments against themselves to a justice of the peace for a small fee.

Far from the picture legal historians have presented of a court system performing a role almost perfectly responsive to the economic and social needs of the community, we can conclude that the courts in New England did not provide the economic benefits that a debt-recording system, such as the modern UCC, achieves by reducing or eliminating uncertainty over collection. In the colonial period, creditors and debtors, as a general matter, incurred the costs of creditors' uncertainty about their priority with respect to other creditors, creditors' uncertainty about the nature of debtors' other debts, and the costs of litigating in an expensive system when creditors feared that they would not otherwise be repaid.

A separate contribution of the Dissertation is to reveal the importance of monetary history to our understanding of the court system and legal doctrine in the seventeenth and eighteenth centuries. During much of the colonial period, the New England economy largely functioned without the widespread circulation of currency (paper or spe-

${ }^{16}$ See Soltow, Economic Role, pp. 140-42. W. T. Baxter's review of the debt collection practices of the Hancock family in Massachusetts led him to conclude similarly that "[a]most every account tells the same long- drawn-out story of dawdle and delay." Baxter, House, p. 192.

${ }^{17}$ See Roeber, Faithful Magistrates, pp. 85, and 73-95.

${ }^{18}$ Harrington, New York Merchant, p. 119.

${ }^{19}$ Letter from William Plumer to John Hale (13 August 1786), in Publications of the Colonial Society of Massachusetts, vol. 11, p. 386.

${ }^{20}$ Letter from William Plumer to John Hale (20 September 1786), in Publications of the Colonial Society of Massachusetts, vol. 11, p. 392.

${ }^{21}$ See Taylor, Western Massachusetts, p. 198 n. 21, citing Newton, Independent Chronicle (Boston), 8 June 1786.

${ }^{22}$ 1786-1787 The Acts and Resolves Public and Private of the Province of MassachusettsBay, pp. 105-11, chap. 43. 
cie). ${ }^{23}$ The scarcity of cash was profoundly important in determining the types of contractual obligations entered into by individuals. Being constrained to "quasi-barter" exchanges greatly suppressed economic activity and reinforced an economic system based upon intracommunity exchanges and localism. Horwitz's emphasis on the prevalence of contracts involving direct exchanges of goods and transfers of property focused on a set of phenomena that might be better regarded as the effects on the legal system of a scarcity of currency than a "premarket" ideology. Understanding the difficulties of exchange without a circulating currency and the ways in which colonial merchants ameliorated those difficulties suggests a more materialist explanation of the communitarian aspects of early colonial society. Intracommunity contractual relationships were reinforced by economic conditions and were not necessarily driven by (although in some areas they plausibly coincided with) a pre-industrial, communitarian mindset. New England citizens involved in the market, however, aggressively advocated the adoption of private and governmental currencies as early as 1682 , expecting that widespread availability of currency would lead to economic advance. As a consequence, the evidence Horwitz explained would change once currency became more widely available and markets developed whether judges actively promoted economic advance or not.

The importance of currency policies and macroeconomic conditions in propelling litigation during particular periods reveals that legal historians' narrow focus on highly localized sources of law has been misguided. To the extent currency policies affected litigation trends, "law" should not be characterized as created exclusively by endogenous processes. The influence of currency issuance and currency policies on civil litigation reveals that even litigation on book accounts - the most community-oriented form of economic relations-reflected colonial responses to conditions of monetary scarcity generated by the English Board of Trade and Parliament, thousands of miles away. Local communities and the norms prevailing within them were irrelevant to the process of establishing and implementing currency policies. Court fees similarly were determined by colonial legislatures and were not entirely sensitive to the moral climate of local communities. Although the fact that colonial courts reliably and mechanically enforced debt agreements was essential to colonial economic growth, the policies of the colonial courts deserve far more scrutiny by economic historians than they have received thus far.

\section{ClAIRE PRIEST, Northwestern University School of Law}

${ }^{23}$ Currency scarcity also had tremendous implications for the nature of government. New England colonial governments in the seventeenth century, for example, were often required to tax in commodity currencies, such as corn and wheat, because the citizenry lacked other currencies with which to satisfy their tax obligations. This limited the extent to which government institutions could finance and realistically expand the scope of their operations.

\section{REFERENCES}

Adams, John. "Novanglus; or, A History of the Dispute with America, from its Origin, in 1754, to the Present Time." In The Works of John Adams, vol. 4, edited by Charles Francis Adams, 49. Boston, Charles C. Little \& James Brown 1851.

Baxter, W. T. The House of Hancock: Business in Boston, 1724-1775. Cambridge MA: Harvard University Press, 1945, reprint, 1965.

Publications of the Colonial Society of Massachusetts. Boston, 1910.

Davis, Andrew McFarland, ed. Colonial Currency Reprints, 1682-1751, vol. 3. Boston: The Prince Society, 1910.

. Colonial Currency Reprints, 1682-1751, vol. 4. Boston: The Prince Society, 
1911.

Horwitz, Morton J. The Transformation of American Law, 1780-1860. Cambridge, MA: Harvard University Press, 1977.

Harrington, Virginia D. The New York Merchant on the Eve of the Revolution. New York: Columbia University Press, 1935.

Konig, David Thomas, ed. Plymouth Court Records, 1686-1859, vols. 5-7, 9-10. Wilmington, DE: Michael Glazier, Inc. in association with the Pilgrim Society, 1978-1981.

Mann, Bruce H. Neighbors and Strangers: Law and Community in Early Connecticut. Chapel Hill: University of North Carolina Press in association with the American Society for Legal History, 1987.

Nelson, William E. Dispute and Conflict Resolution in Plymouth County, Massachusetts, 1725-1825. Chapel Hill: University of North Carolina Press, 1981.

Roeber, A. G. Faithful Magistrates and Republican Lawyers: Creators of Virginia Legal Culture, 1680-1810. Chapel Hill: University of North Carolina Press, 1981.

Soltow, James H. The Economic Role of Williamsburg. Williamsburg: University Press of Virginia, 1965.

Taylor, Robert J. Western Massachusetts in the Revolution. Providence, RI: Brown University Press, 1954.

\section{Comments on Moser, Herranz-Loncán, and Li}

On the last day of July 1851, Lorenza Berbineau, a Boston servant girl who accompanied the family of Francis Cabot Lowell II on their tour of Europe, "went to Hyde Park to the great Exhibition." In breathless prose, she exalted:

It was magnificent I saw things from the United States handsome lamps machinery farming emplements ... from France saw a splendid door of Malachite green also tables Chairs vases some say it is stone some say it is a Metal it was taken from a mine I saw the Horse in Bronze the wild horse there was two men tying a man on to him I saw a wrought silks \& caps wrought with gold thread a great many Swiss things cut from wood ... some Turkey carpets also French Tapestry Carpets there were two large Diamon I was told the man who cut it was put in Prison for 21 years for cutting it so badly ... I saw some Vases made from Cannel Coal they looked like black Ebony ... there was a good deal of machinery from Different parts of the world some of it was in motion I saw them make bricks they put the clay in it came out formed into brick ... I was there about 3 hours to day I got very tired. ${ }^{1}$

The sense of being overwhelmed by the richness, variety and sheer volume of the Great Exhibition at Crystal Palace (there were over 100,000 objects on display) was a common reaction among visitors. Both Charles Dickens and Lewis Carroll acknowledged their "bewilderment" while James Ward described his "state of mental helplessness" in the face of such a phantasmagoria.

Petra Moser finds herself in no such state of mental helplessness. She has walked (metaphorically, of course) along the more than 20 miles of aisles and paths that traversed the exhibition grounds of Hyde Park, cataloguing and classifying the exhibits. Moreover, she has done this not just for the Crystal Palace, but also for the Centennial Exhibition in Philadelphia a generation later. She has meticulously catalogued almost 33,000 exhibits by industry of application, country of origin, geographical location

\footnotetext{
${ }^{1}$ Berbineau, From Beacon Hill.
} 